\title{
RASSF1A-LATS1 signalling stabilizes replication forks by restricting CDK2-mediated phosphorylation of BRCA2
}

Dafni-Eleftheria Pefani, Robert Latusek, Isabel Pires, Anna M. Grawenda, Karen S. Yee, Garth Hamilton, Louise van der Weyden, Fumiko Esashi, Ester M. Hammond and Eric O’Neill

Nat. Cell Biol. 16, 962-971 (2014); published online 14 September 2014; corrected after print 11 March 2015

In the original version of this Article, the bar chart in Fig. 6 was incorrect; the corrected chart is shown below. This has now been corrected in all online versions of this Article.

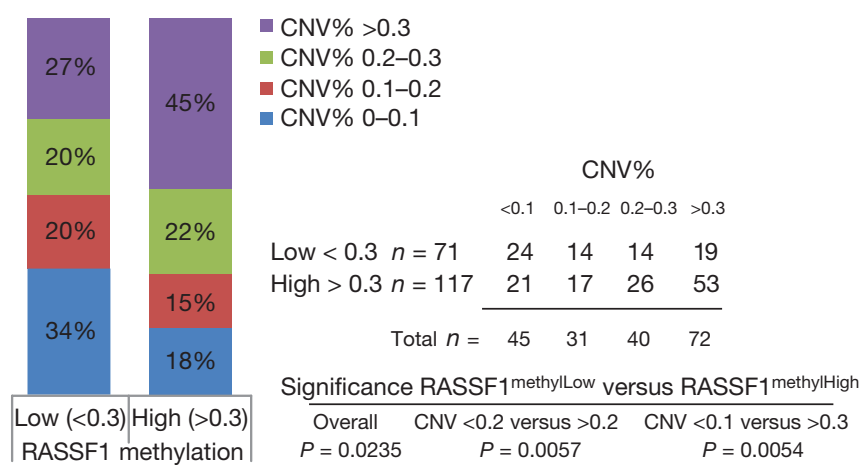

